\title{
Physiological responses of Pterocladiella capillacea (Rhodophyta, Gelidiales) under two light intensities
}

\author{
T.B. HARB ${ }^{+}$, A. NARDELLI, and F. CHOW \\ Institute of Bioscience, University of São Paulo, São Paulo, SP, CEP 05508-090, Brazil
}

\begin{abstract}
Macroalgae must be able to survive in conditions of different light intensities with no damage to their physiological performance or vital processes. Irradiance can stimulate the biosynthesis of certain photoprotective compounds of biotechnological interest, such as pigments and proteins. Pterocladiella capillacea is a shade-grown alga, which play a role key in the balance of marine ecosystems. In addition, it is considered one of the best sources of bacteriological agar and agarose with a wide pharmacological potential. In order to evaluate the photosensitivity in $P$. capillacea under 60 (control) and moderate light intensity of $300 \mu \mathrm{mol}$ (photon) $\mathrm{m}^{-2} \mathrm{~s}^{-1}$, photosynthetic performance and chemical composition were assessed. $P$. capillacea showed photosensitivity without evidence of photodamage. The results indicate the possibility to increase a growth rate and probably infer productivity in long-term cultivation by stimulation at moderate light intensity. Increasing photosynthetic pigment and protein contents were also observed under medium light, an interesting result for functional ingredient approaches.
\end{abstract}

Additional key words: algae; chlorophyll fluorescence; growth rate; pigments; productivity; radiation.

\section{Introduction}

The energy associated with ultraviolet (UV) radiation and photosynthetically active radiation (PAR) determines the photosynthetic capacity of macroalgae and is frequently associated with photosensitivity, phototolerance, photoinhibition, and photodamage processes when it exceeds the photochemical demand or energy dissipation capacity of organisms (Hanelt and Figueroa 2012). Photosynthetic photoinhibition occurs under excessive light availability where the irradiance is greater than the acclimation capacity, causing a reduction of photosynthetic activity (Asada 1994, Takahashi and Murata 2008, Hou and Hou 2013). High intensities of solar radiation can cause photoinhibition or even cellular death due to the inability of certain algae to adjust their composition or concentration of pigments at high irradiances (Hanelt et al. 2006, Gómez and Huovinen 2011, Figueroa et al. 2014a). Photodamage is usually associated with oxidative stress through the overproduction of reactive oxygen species, reactive nitrogen species and their derivatives (Hideg et al. 1994, Hanelt et al. 2006, Takahashi and Badger 2011). Oxidative stress has also been associated with specific cleavage of the D1 protein, a component of PSII, activating certain defense mechanisms, such as the production of antioxidant compounds (Nishiyama et al. 2004) and the activity of specific antioxidant enzymes (Lee and Shiu 2009, dos Santos et al. 2012).

In seaweeds, oxidative stress can cause DNA mutation, protein denaturation, lipid peroxidation, loss of pigments, and alterations in membrane integrity, the latter photochemically affecting photosystems (Cherry and Nielsen 2004). Changes in physiological responses have also been identified and variations in photosynthetic parameters for macroalgae, such as the maximal quantum yield of PSII $\left(\mathrm{F}_{\mathrm{V}} / \mathrm{F}_{\mathrm{M}}\right)$, have already been reported (Liu and Pang 2010).

Received 21 February 2017, accepted 18 August 2017, published as online-first 12 April 2018.

${ }^{+}$Corresponding author; phone: $+55+11+30918068$, fax: $+55+11+30917546$, e-mail: talissaharb@ib.usp.br

Abbreviations: A - absorptance; Ab - absorbance; APC - allophycocyanin; DM - dry mass; Car - carotenoids; Chl - chlorophyll; $\mathrm{CL}$ - control irradiance of $60 \mu \mathrm{mol}\left(\right.$ photon) $\mathrm{m}^{-2} \mathrm{~s}^{-1}$; ETR - electron transport rate; ETR $\mathrm{MAX}$ - maximal electron transport rate; $\mathrm{FM}$ - fresh mass; $\mathrm{F}_{\mathrm{V}} / \mathrm{F}_{\mathrm{M}}$ - maximal quantum yield of PSII photochemistry; $\mathrm{GR}$ - growth rate; $\mathrm{I}_{\mathrm{K}}$ - saturation irradiance; $\mathrm{ML}$ - irradiance of $300 \mu$ mol(photon) $\mathrm{m}^{-2} \mathrm{~s}^{-1}$; PC - phycocyanin; PE - phycoerythrin; PMAX - maximum photosynthesis; TSP - total soluble proteins; UV - ultraviolet; VSES - von Stosch enrichment solution; $\Phi_{P S I I}$ - effective quantum yield of PSII photochemistry; $\mathrm{Y}_{(\mathrm{PSII})}$ - photochemical quenching; $\mathrm{Y}_{(\mathrm{NO})}$ - nonregulated nonphotochemical quenching; $\mathrm{Y}_{(\mathrm{NPQ})}$ - regulated nonphotochemical quenching; $\alpha$-photosynthetic efficiency.

Acknowledgements: The authors thank FAPESP (São Paulo Research Foundation; 2014/09380-3 and Biota/Fapesp 2013/50731-1) and CNPq (National Counsel of Technological and Scientific Development) for financial support and scholarships. F. Chow thanks CNPq for CNPq Research Productivity Scholarship (303937/2015-7). 
Seaweeds are known to contain a range of antioxidant molecules and secondary metabolites, which protect them from oxidative stress (Balboa et al. 2013). Algal species living in the intertidal zone are subjected to diverse solar radiation regimes, depending on their habitat environment, which can result in differences in oxidative stress and antioxidant responses between algal species (Park et al. 2016). Marine algae have the ability to acclimate when exposed to variable light intensities. Under long periods of high light intensity, an accumulation of excess excitation energy usually occurs, consequently inducing photostress conditions. Under this circumstance, phycobiliproteins are the most sensitive pigments, being the first to be degraded, followed by carotenoids (Car) and chlorophyll $a$ (Chl) (Donkor and Häder 1996, Beach et al. 2000). Algae adapted to high light intensity, denoted as sun algae, usually inhabit the supra- and mid-intertidal of the coastal zone on the rocky shore littoral, commonly exposed to elevated levels of solar radiation (Falkowski 1980). These high light-adapted macroalgae show high rates of maximum photosynthesis $\left(P_{\mathrm{MAX}}\right)$, low photosynthetic efficiency $(\alpha)$, high values of saturation irradiance $\left(\mathrm{I}_{\mathrm{K}}\right)$, low Chl content, and high short-term increase of accessory pigments such as Car and phycobiliproteins (Gómez and Huovinen 2011). When exposed to high irradiance, sun algae may increase at a short term the concentration of photosynthetic pigments as a defense mechanism to avoid photosynthetic photosaturation and quench the high incident energy. At the long term or under stronger light stress, the tendency is to degrade pigments as consequence of photodamage and then depigmentation of the thallus occurs (Martone et al. 2010, Betancor et al. 2014.)

On the other hand, algae adapted to low light intensity, denoted as shade algae, commonly inhabit the lower intertidal and upper infralittoral zones or sun-protected shadow areas like crevices, frequently exposed to low light irradiances. Physiologically, shade algae are characterized by low rates of $P_{\mathrm{MAX}}$, high $\alpha$, low values of $\mathrm{I}_{\mathrm{K}}$, and higher concentrations of photosynthetic pigments (Falkowski 1980, Grobbelaar and Kurano 2003, Copertino et al. 2006, Betancor et al. 2014).

Under natural conditions, there is a wide variation of light intensity throughout the day, especially in intertidal environments; therefore, many algae seem to acclimate their light-harvesting complex to distribute the excess of excitation energy among the photosystems in order to avoid photodamage (Falkowski 1980, Franklin et al. 2003). In general, the capacity to use light energy serves as a sensor to regulate the appropriate concentration of pigments to maintain the balance between excitation energy, photochemical ability, and demand for growth (MacIntyre et al. 2000, Necchi 2005). Therefore, marine macroalgae need to be able to absorb light in low- and high-irradiance situations without compromising the photosynthetic process (Franklin and Larkum 1997, Necchi 2005, Sampath-Wiley et al. 2008).

High irradiance can cause nutritional deficiency in macroalgae by an indirect effect on carbon/nitrogen metabolism through cellular organic component reallocation. At excessive light, the photosynthetic machinery is forced beyond the carbon and nitrogen availability, creating a carbon/nitrogen imbalance (Polo et al. 2014). In response to high light, algae can degrade carbon stocks, such as starch and polysaccharides (He et al. 2002, Nyvall-Cóllen et al. 2004), and photosynthetic pigments as a reallocation strategy for providing organic and inorganic components (nitrogen and carbon skeletons, for example) which can be transferred to synthesize other compounds for cell maintenance and defense (MacIntyre et al. 2000).

Nishihara et al. (2005) observed an improvement in nitrate and ammonium uptakes by Laurencia brongniartii J. Agardh with increasing irradiance. The authors attributed this result to the consumption of internal nitrogen reserves due to the rise of photosynthetic activity. The placement of macroalgae in the rocky shore also influences the algal metabolism. Martínez and Rico (2008) observed that algae acclimated to local high irradiances usually have a higher carbon and lower nitrogen contents when compared to acclimated algae from areas with low irradiances.

For this study, Pterocladiella capillacea (S.G. Gmelin) Santelices \& Hommersand (Rhodophyta, Gelidiales) was chosen as a biological model because it is a species ecologically relevant and abundant in shadow intertidal rocky shores (Oliveira et al. 1996). The Pterocladiella beds are natural nurseries for many marine species, mainly marine invertebrates, such as crustaceans, amphipods, polychaetes, among others; they also serve as refuge for several organisms (Nascimento and Rosso 2007). Additionally, $P$. capillacea is one of the most studied species of Gelidiales in Brazil, due to the great ecological and economic importance for human consumption and extraction of good quality agar (Oliveira et al. 1996). This species is characterized as a shade alga, commonly in lower intertidal and shallow subtidal, inhabits crevices and wave-beaten locals, attached to consolidate substrate, generally in the rocky shore (Gal-Or and Israel 2004). It is widely found in the Brazilian coast, from the state of Espírito Santo to the coast of Rio Grande do Sul (Guimarães 2006).

As an ecologically and economically important species, the elucidation of acclimation, sensitivity, tolerance, and defense mechanisms of $P$. capillacea under moderate light conditions are valuable physio-chemical informations. The aim of this study was to evaluate the photosensitivity and tolerance mechanisms of $P$. capillacea under two light intensities (a control treatment and at moderate irradiance) to assess the possibility to improve a growth rate and chemical composition for further biotechnological applications. The results of the present study can complement previous ecological and physiological studies and the knowledge regarding the life strategy of $P$. capillacea under increasing irradiance. The understanding of these processes can enable the management and sustainable exploitation of the species. 


\section{Materials and methods}

Alga material, culture conditions and growth rate (GR): Pterocladiella capillacea was collected in September 2014 at Praia da Cruz $\left(21^{\circ} 02^{\prime} 01.68^{\prime \prime S}\right.$; $\left.40^{\circ} 48^{\prime} 44.43^{\prime \prime} \mathrm{W}\right)$, Espírito Santo State, in the southeastern region of Brazil. Distal segments of $10 \mathrm{~cm}$ in length of $P$. capillacea were maintained in sterile seawater (32 psu) and von Stosch enrichment solution (VSES) 100\% [Ursi and Plastino (2001) modified from Edwards (1970)]. The algae were acclimated for one week in a temperaturecontrolled room at $25 \pm 1^{\circ} \mathrm{C}$ with a photoperiod of $14 \mathrm{~h}$, irradiance of $60 \mu \mathrm{mol}$ (photon) $\mathrm{m}^{-2} \mathrm{~s}^{-1}$, and intermittent aeration for $30 \mathrm{~min}$, at the culture proportion of $3 \mathrm{~g}$ of biomass for $1 \mathrm{~L}$ of culture medium. Eight specimens were deposited in the SPF Herbarium of the University of São Paulo (voucher SPF-57890).

After acclimation, distal algal portions $(7 \mathrm{~cm})$ were submitted to two light treatments, provided as PAR of 60 (CL) and $300 \mu \mathrm{mol}\left(\right.$ photon) $\mathrm{m}^{-2} \mathrm{~s}^{-1}$ (ML) $(n=5)$ for eight experimental days, in total of 80 Erlenmeyer flasks, and the same culture acclimation conditions described below. With the aim of studying a moderate light intensity, $300 \mu \mathrm{mol}$ (photon) $\mathrm{m}^{-2} \mathrm{~s}^{-1}$ was chosen as moderate irradiance, since 10-times higher irradiation is considered a high stressing light (Torres et al. 2014). Biological independent replicates for each treatment and experimental period were cultivated in separated Erlenmeyer flasks. Experimental measurements were carried out at $0,1,3,5,7$, and 8 $(\mathrm{t} 0, \mathrm{t} 1, \mathrm{t} 3, \mathrm{t} 5, \mathrm{t} 7$. and $\mathrm{t} 8) \mathrm{d}$ by the analysis of growth rate (GR), photosynthetic performance, cellular carbonhydrogen-nitrogen (CHN) content, pigments, and total soluble proteins (TSP). Time t0 represents the treatment before starting the experimental condition and $t 8$ represents the treatment after a 24-h supplementation with VSES $100 \%$. The objective of this last time (t8) was to evaluate the recovery of $P$. capillacea.

GR was estimated by the equation: GR ( $\%$ per day $)=$ $\left[\left(\mathrm{M}_{\mathrm{f}} / \mathrm{M}_{\mathrm{i}}\right)^{1 / \mathrm{t}}-1\right] \times 100 \%$ (Penniman et al. 1986$)$, where $\mathrm{M}_{\mathrm{f}}$ is the final fresh mass (FM) at final experimental time $(\mathrm{t})$, $\mathrm{M}_{\mathrm{i}}$ is the initial fresh mass, and the results were represented as daily average GR.

In vivo Chl $\boldsymbol{a}$ fluorescence: Photosynthetic performance was estimated as in vivo fluorescence of Chl $a$ of PSII by using a portable fluorometer PAM-2500 (Walz, Germany). The measurements were made between 4 and $7 \mathrm{~h}$ after switching on the photoperiod light. $\mathrm{F}_{\mathrm{V}} / \mathrm{F}_{\mathrm{M}}$ was measured in 15-min dark-adapted sample and calculated following Schreiber et al. (1986). Effective quantum yield of PSII

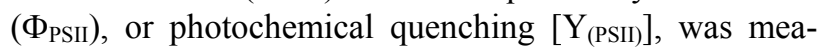
sured in light-adapted sample and calculated following Schreiber and Neubaer (1990). Photosynthesis-irradiance curves were estimated on light-adapted samples from electron transport rate (ETR)-irradiance curves at eight increasing actinic irradiances [PAR: 0, 24, 61, 108, 186, 456, 752, and 1,024 $\mu$ mol(photon) $\mathrm{m}^{-2} \mathrm{~s}^{-1}$ ]. ETR was calculated as $\mathrm{ETR}=\Phi_{\mathrm{PSII}} \times \mathrm{PAR} \times \mathrm{A} \times 0.15$; where $\mathrm{A}$ is the absorptance (Ramus and Rosenberg 1980, Mercado et al. 1996) and 0.15 is the fraction of Chl $a$ associated with PSII for red algae. The Chl $a$ fraction is different from that of green algae or vascular plants (0.5) and brown algae (0.8), since lower Chl $a$ is associated to the PSII in red algae (Grzymski et al. 1997). From the ETR-irradiance curves, the maximum ETR (ETR $\left.\mathrm{EAX}_{\mathrm{A}}\right), \alpha$, and $\mathrm{I}_{\mathrm{K}}$ were determined (Maxwell and Johnson 2000) by fitting the curves to a hyperbolic tangent model of Jassby and Platt (1976). Photochemical quenching $\left[\mathrm{Y}_{(\mathrm{PSII})}\right]$, nonregulated nonphotochemical quenching $\left[\mathrm{Y}_{(\mathrm{NO})}\right]$, and regulated nonphotochemical quenching $\left[\mathrm{Y}_{(\mathrm{NPQ})}\right]$ were also determined using the method of Roháček (2002).

Photosynthetic pigments and total soluble proteins (TSP): Frozen samples of $70 \mathrm{mg}(\mathrm{FM})$ were ground in liquid nitrogen and extracted into $1.5 \mathrm{~mL}$ of ice-cold $0.05 \mathrm{M}$ phosphate buffer ( $\mathrm{pH} 5.5$ ). The homogenate was centrifuged at $12,000 \mathrm{rpm}$ and $4{ }^{\circ} \mathrm{C}$ for $15 \mathrm{~min}$ and the supernatant analyzed in a UV-visible spectrophotometer (Epoch Biotek, USA) for phycobiliprotein determination $\left[\mu \mathrm{g} \mathrm{g}^{-1}(\mathrm{FM})\right]$ according to the formulas (Kursar et al. 1983): $\mathrm{PE}$ (phycoerythrin) $=\left(155.8 \times \mathrm{Ab}_{498}\right)-(40 \times$ $\left.\mathrm{Ab}_{614}\right)-\left(10.5 \times \mathrm{Ab}_{652}\right), \mathrm{PC}$ (phycocyanin) $=(151.1 \times$ $\left.\mathrm{Ab}_{614}\right)-\left(99.1 \times \mathrm{Ab}_{652}\right)$, and APC (allophycocyanin) $=$ $\left(181.3 \times \mathrm{Ab}_{652}\right)-\left(22.3 \times \mathrm{Ab}_{614}\right)$; where $\mathrm{Ab}$ represents the absorbance at the respective wavelength. The concentration of TSP was estimated from the same supernatant following Bradford (1976) by using Bio-Rad $\AA$ protein assay reagent (Bio-Rad, USA) and bovine serum albumin as standard. Chl $a$ and Car analyses were performed using the resulting pellet of phycobiliproteins and protein extraction by resuspending the sedimented material in $1 \mathrm{~mL}$ of methanol extracted for $3 \mathrm{~h}$ at $4^{\circ} \mathrm{C}$ and protected from light (Wanderley 2009). The homogenate was centrifuged at $12,000 \mathrm{rpm}$ at $4^{\circ} \mathrm{C}$ for $15 \mathrm{~min}$ and the supernatant was analyzed in a UV-visible spectrophotometer (Epoch Biotek, USA). Concentrations of Chl $a$ and Car were calculated from their absorbances based on the formulas: Chl $a\left[\mu \mathrm{g} \mathrm{g}^{-1}(\mathrm{FM})\right]=\left(12.61 \times 153 \mathrm{Ab}_{664}\right)$ and $\operatorname{Car}\left[\mu \mathrm{g} \mathrm{g}^{-1}(\mathrm{FM})\right]=\left(1000 \times \mathrm{Ab}_{470}-1.63 \times \mathrm{Chl} a\right) / 221$ as modified from Lichtenthaler and Buschmann (2001).

Carbon-hydrogen-nitrogen ( $\mathrm{CHN}$ ) contents: The quantification of cellular $\mathrm{CHN}$ was performed at the Analytical Center of the Chemistry Institute of USP using a PerkinElmer 2400 elemental composition analyser (PerkinElmer, USA). Dry samples $\left(60^{\circ} \mathrm{C}\right)$ of $500 \mathrm{mg}$ were ground to a fine powder and aliquots of $1 \mathrm{mg}$ were ashed at $925^{\circ} \mathrm{C}$ under pure oxygen, causing complete oxidation of the material. All $\mathrm{C}$ was converted to $\mathrm{CO}_{2}$. $\mathrm{N}$ was changed into several oxides $\left(\mathrm{N}_{\mathrm{x}} \mathrm{O}_{\mathrm{x}}\right)$ and then to $\mathrm{N}_{2}$ by reduction. Individual components were separated from the resultant mixture in a chromatographic column $\left(640^{\circ} \mathrm{C}\right)$ and 
detected through thermal conductivity changes of the products. The total $\mathrm{CHN}$ content was calculated as a percentage, in which each element was standardized to the dry mass (DM) of seaweed and expressed as $\mathrm{mg} \mathrm{g}^{-1}(\mathrm{DM})$.

Data analysis: All parameters were studied with five replicates for each treatment and each experimental time.

\section{Results}

GR and in vivo Chl $\boldsymbol{a}$ fluorescence: The GR of $P$. capillace $a$ at the end of the experimental period increased more than two fold at $300 \mu \mathrm{mol}$ (photon) $\mathrm{m}^{-2} \mathrm{~s}^{-1}$ (ML) $(2.68 \pm$ $0.07 \% \mathrm{~d}^{-1}$ ) regarding to control (CL) at $60 \mu \mathrm{mol}$ (photon) $\mathrm{m}^{-2} \mathrm{~s}^{-1}\left(0.71 \pm 0.19 \% \mathrm{~d}^{-1}\right)$. On the other hand, photosynthetic performance showed a moderate variation between both treatments over experimental time. At control irradiance, the $\mathrm{F}_{\mathrm{V}} / \mathrm{F}_{\mathrm{M}}$ were constant over time (data not shown). In contrast, there was a decrease in $\mathrm{F}_{\mathrm{V}} / \mathrm{F}_{\mathrm{M}}$ and variable $\Phi_{\text {PSII }}$ over the days under ML (data not shown). The A was also constant at both irradiances over time (data not shown).

$\mathrm{Y}_{\text {(PSI) }}$ showed no variation over the days at $\mathrm{CL}$ irradiance (Fig. 1), in contrast, at ML, the $\mathrm{Y}_{\text {(PSII) }}$ declined starting from $\mathrm{t} 3$ with the lowest value at $\mathrm{t} 7$ (Fig. 1). Comparing the $\mathrm{Y}_{\text {(PSII) }}$ between irradiance treatments, the yield was reduced at ML. The $\mathrm{Y}_{(\mathrm{NO})}$, which is the heat dissipation without energy expenditure, was greater at ML than that at CL (Fig. 1). The $\mathrm{Y}_{(\mathrm{NPQ})}$, which is the energy dissipation with energy expenditure (e.g., xanthophyll cycle), was also estimated, but no values were registered at any irradiance (Fig. 1).

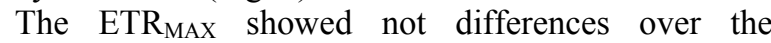

Data were statistically analyzed with the Statistica 12 software by previously testing normality (KolmogorovSmirnov's test) and homoscedasticity (Bartlett's test) $(p<0.05)$ and then analyzed by a repeated measures analysis of variance (ANOVA) and Newman-Keul's multiple-comparison post-hoc test $(p<0.05)$.

experimental time for the irradiances, except for $\mathrm{t} 7$ at $\mathrm{CL}$ (Fig. 2A). The $\alpha$ did not vary over time for the two irradiance treatments (Fig. $2 B$ ). $\mathrm{I}_{\mathrm{K}}$ under $\mathrm{CL}$ showed increasing difference only at $\mathrm{t} 5$ and $\mathrm{t} 7$ (Fig. $2 C$ ), whereas at $\mathrm{ML}$, the greatest $\mathrm{I}_{\mathrm{K}}$ was observed at $\mathrm{t} 7$.

ETR-irradiance curves over time for $\mathrm{CL}$ and $\mathrm{ML}$ are shown in Fig. $3 A$ and $3 C$, respectively. Different dynamic plots were observed when compared the two light intensities, however, no clear pattern was noted. For CL, an increasing curve was observed at $\mathrm{t} 7$ (Fig. $3 A$ ), with a significant area under the curve of 2,803 \pm 288 (Fig. 3B). For other experimental times at the same irradiance, the curve plots were similar and no differences were observed for the area under the curves (Fig. 3A,B). At ML, the ETRPAR curve plots (Fig. $3 C$ ) and the areas under the curves (Fig. 3D) remained constant until the end of the experiment without statistical differences.

Table 1 shows the photosynthetic parameters of $P$. capillacea under the effect of increasing PAR. In the present study, none of the irradiations tested activated $\mathrm{Y}_{(\mathrm{NPQ})}$ and $P$. capillacea did not dissipate heat with energy expenditure.

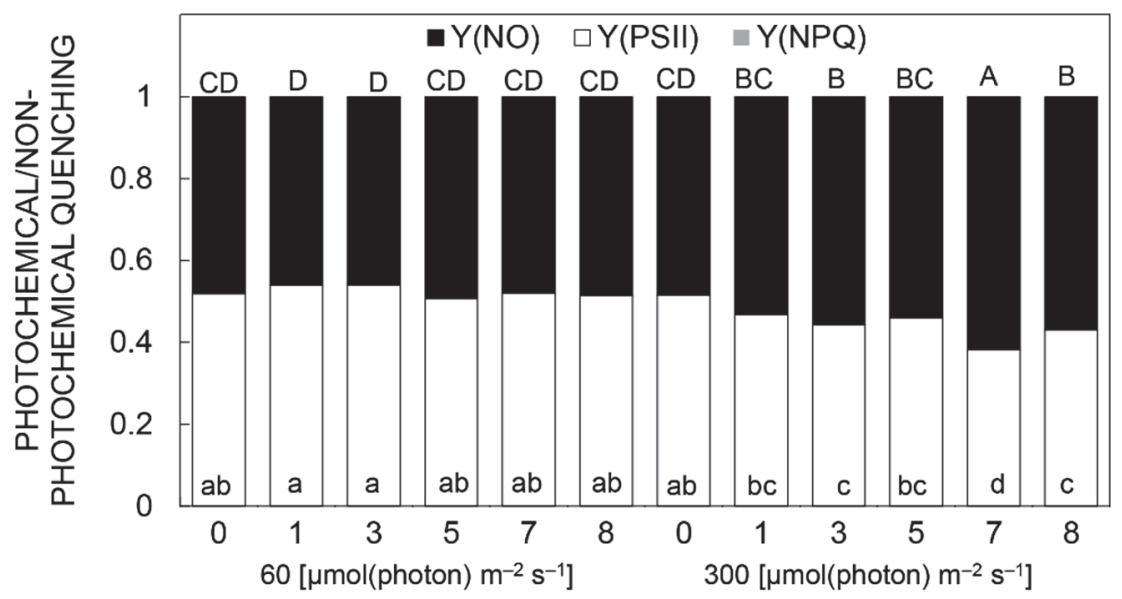

Fig. 1. Photosynthetic performance (mean $\pm \mathrm{SD}, n=5$ ) of Pterocladiella capillacea under 60 and $300 \mu \mathrm{mol}(\mathrm{photon}) \mathrm{m}^{-2} \mathrm{~s}^{-1}$ over the experimental time, measured as $\mathrm{Y}_{(\mathrm{NO})}$ - nonregulated nonphotochemical quenching, $\mathrm{Y}_{(\mathrm{PSII})}-$ photochemical quenching, and $\mathrm{Y}_{(\mathrm{NPQ})}-$ regulated nonphotochemical quenching. Different letters represent statistically differences by repeated-measure ANOVA and post hoc Newman-Keuls test $(p<0.05)$. 


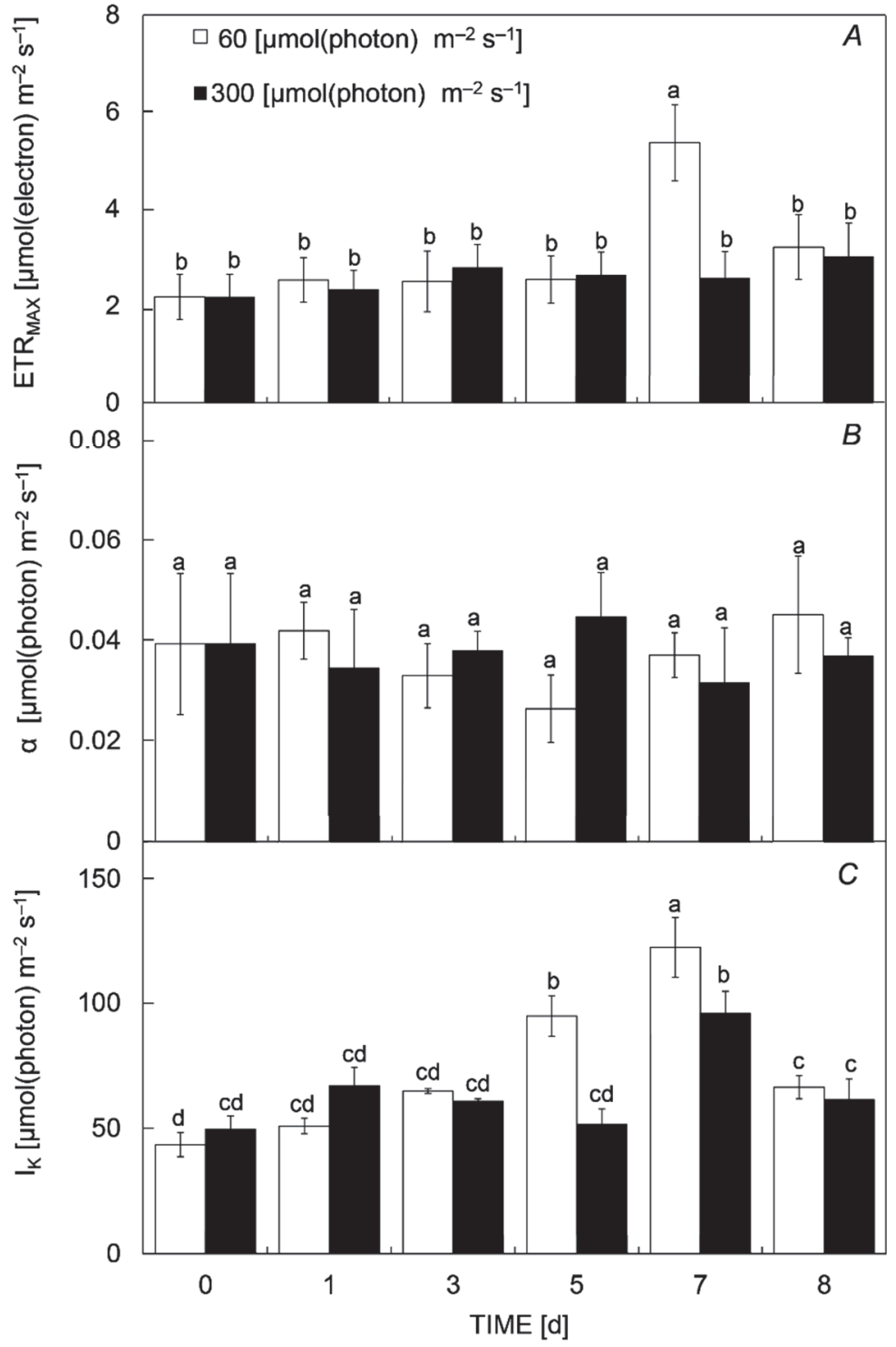

Fig. 2. Photosynthetic performance (mean $\pm \mathrm{SD}$, $n=5$ ) of Pterocladiella capillacea under 60 (white bars) and $300 \mu \mathrm{mol}\left(\right.$ photon) $\mathrm{m}^{-2} \mathrm{~s}^{-1}$ (black bars) over the experimental time, measured as $(A)$ ETRMAX - maximum electron transport rate, $(B)$ $\alpha$ - photosynthetic efficiency, and $(C) \mathrm{IK}_{\mathrm{K}}$ - saturation irradiance. Different letters represent statistically differences by repeated-measure ANOVA and post hoc Newman-Keuls test $(p<0.05)$.
Photosynthetic pigments, TSP and CHN contents: For phycobiliproteins, a gradual increase over time in samples under $\mathrm{CL}$ was observed, with a greater pigment content at t8 (Fig. $4 A-C$ ). For ML, however, PE and PC decreased over the days when compared with t0 (Fig. 4A-C). Different responses were observed for $\mathrm{Chl} a$, where for both irradiances, Chl $a$ decreased over the days (Fig. 4D). No differences were observed in the total Car contents when the experimental times were compared with the respective t0 (Fig. 4E).

\section{Discussion}

The knowledge of the chemical composition (CHN, pigment, and TSP contents) and physiological parameters (GR and photosynthetic performance) under increasing irradiance presented here provides an important basis for understanding the photosensitivity of the species. P. capillacea showed the photosensitivity to the treatment of
TSP results (Fig. 4F) showed that, for both irradiances, there was an increase from the $\mathrm{t} 3$ when compared to $\mathrm{t} 0$. For the two light treatments, the same contents of proteins were observed.

For the cellular CHN content, no variations between the days and irradiance treatments were observed in $\mathrm{C}$ (Fig. 5A), $\mathrm{H}$ (Fig. 5B) or $\mathrm{N}$ (Fig. 5C).

The results of repeated-measured $A N O V A$ for all studied parameters is shown in Table 1S (supplement available online).

moderate light intensity, however, no photodamage was observed. Our results indicate that the species turn on defense mechanisms of efficient phototolerance, especially nonphotochemical nonregulated quenching of excess of energy and regulatory synthesis/degradation of the photosynthetic antenna complex. Thus, $P$. capillacea 
showed high efficiency in photoacclimation under the laboratory conditions tested in this study and request low light intensity to maintain their life processes.

The increase in irradiance positively affected the GR of $P$. capillacea, however, a reduction in photosynthetic parameter ( $\mathrm{Y}_{(\mathrm{PSI})}, \mathrm{ETR}_{\mathrm{MAX}}$, ETR curves) at moderate light intensity were observed. The decrease in photosynthesis was coupled with energy dissipation by $\mathrm{Y}_{(\mathrm{NO})}$, indicating passive heat energy dissipation. This quenching mechanism is an efficient process when there is a reduction of photosynthetic expenditure without a GR reduction (Klughammer and Schreiber 2008). These results indicate that $300 \mu \mathrm{mol}$ (photon) $\mathrm{m}^{-2} \mathrm{~s}^{-1}$ under the experimental conditions studied here did not represent a severe stress conditions that could negatively affect the photodynamics of the photosynthetic apparatus.

As a shade alga, moderate or higher irradiances of $P$. capillacea would be expected to negatively affect GR and photosynthesis, since it inhabits shaded sites, preferably crevices protected from the direct incidence of light, often found in the lower intertidal zone, where it is constantly in contact with seawater. Similar results were obtained by Gómez et al. (2004) for some species from a different intertidal localizations. Photosynthetic parameters are valuable descriptors for analyzing the sensitivity and recovery of macroalgae under variable abiotic conditions, making possible to assess acclimation and stress responses. Gal-Or and Israel (2004) showed that irradiances during winter time, 100-500 $\mu$ mol(photon) $\mathrm{m}^{-2} \mathrm{~s}^{-1}$, stimulated GR of $P$. capillacea; on the other hand, higher summer irradiances [400-800 $\mu \mathrm{mol}$ (photon) $\mathrm{m}^{-2} \mathrm{~s}^{-1}$ ] decreased the GR of the species. In Espírito Santo, the place of origin of our material, the monthly mean irradiance during the summer is around $1,012 \mu \mathrm{mol}$ (photon) $\mathrm{m}^{-2} \mathrm{~s}^{-1}$ and in the winter it is $512 \mu \mathrm{mol}$ (photon) $\mathrm{m}^{-2} \mathrm{~s}^{-1}$ (data provided by the Center for Weather Forecasting and Climate Studies in Brazil), similar values to those reported by Gal-Or and Israel (2004). In this sense and considering the results of this study, we can assume that levels above 500-600 $\mu$ mol(photon) $\mathrm{m}^{-2} \mathrm{~s}^{-1}$ should be adverse conditions for $P$. capillacea. At low irradiances, 120 and 190 $\mu \mathrm{mol}\left(\right.$ photon) $\mathrm{m}^{-2} \mathrm{~s}^{-1}$, Sudatti et al. (2011) also verified growth rate increase for Laurencia dendroidea J. Agardh; results were interpreted by the authors as nonphotoinhibitory conditions. A ten-fold elevated irradiance [600 $\mu \mathrm{mol}\left(\right.$ photon) $\mathrm{m}^{-2} \mathrm{~s}^{-1}$ ] compared to the experimental

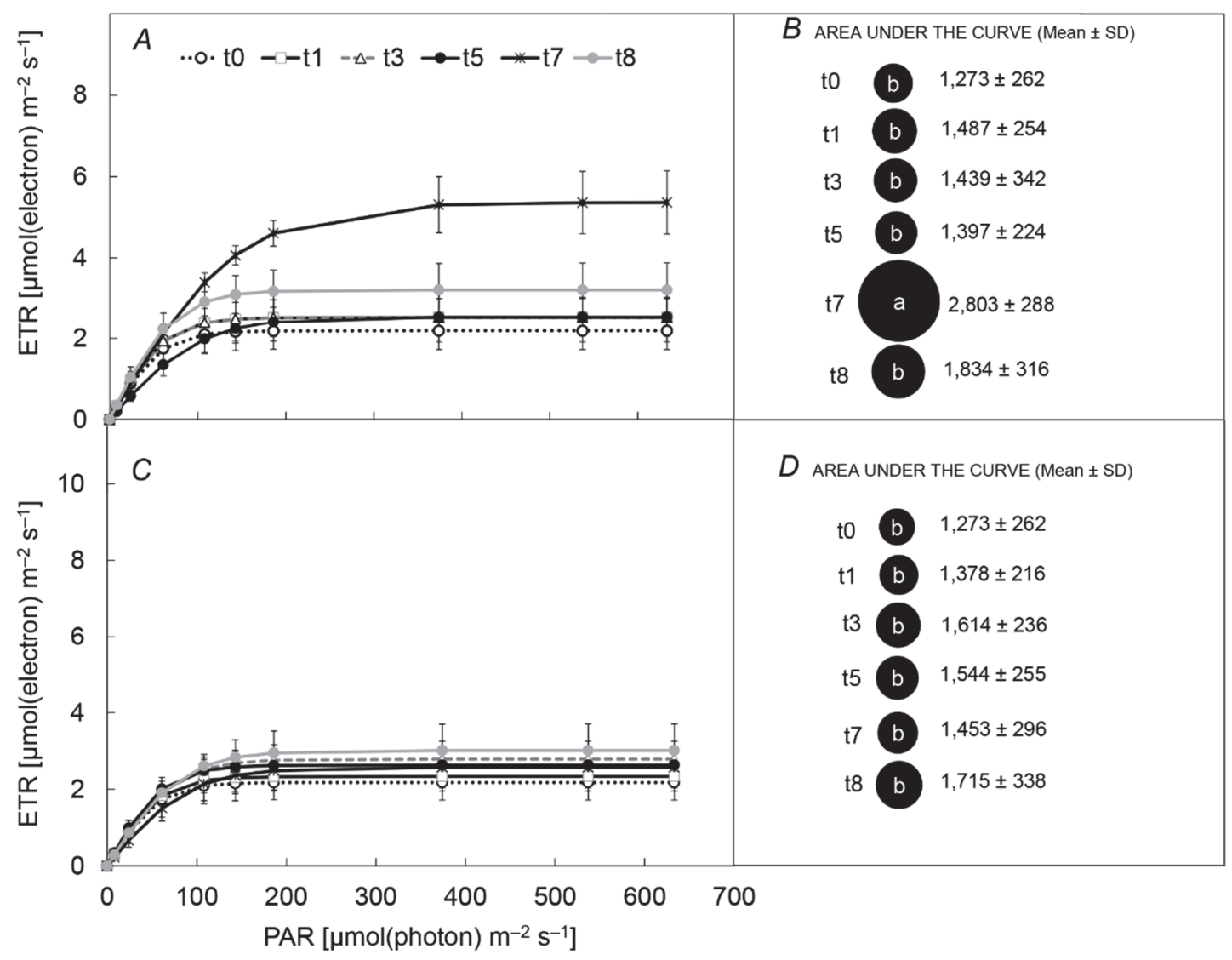

Fig. 3. Electron transport rate (ETR)-PAR curves and the respective area under the curve (mean $\pm \mathrm{SD}, n=5$ ) of Pterocladiella capillacea over the experimental time for $(A-B) 60 \mu \mathrm{mol}$ (photon) $\mathrm{m}^{-2} \mathrm{~s}^{-1}$ and $(C-D) 300 \mu \mathrm{mol}$ (photon) $\mathrm{m}^{-2} \mathrm{~s}^{-1}$. Different letters for values of area under the curve represent statistically differences by repeated-measure ANOVA and post hoc Newman-Keuls test $(p<0.05)$. 


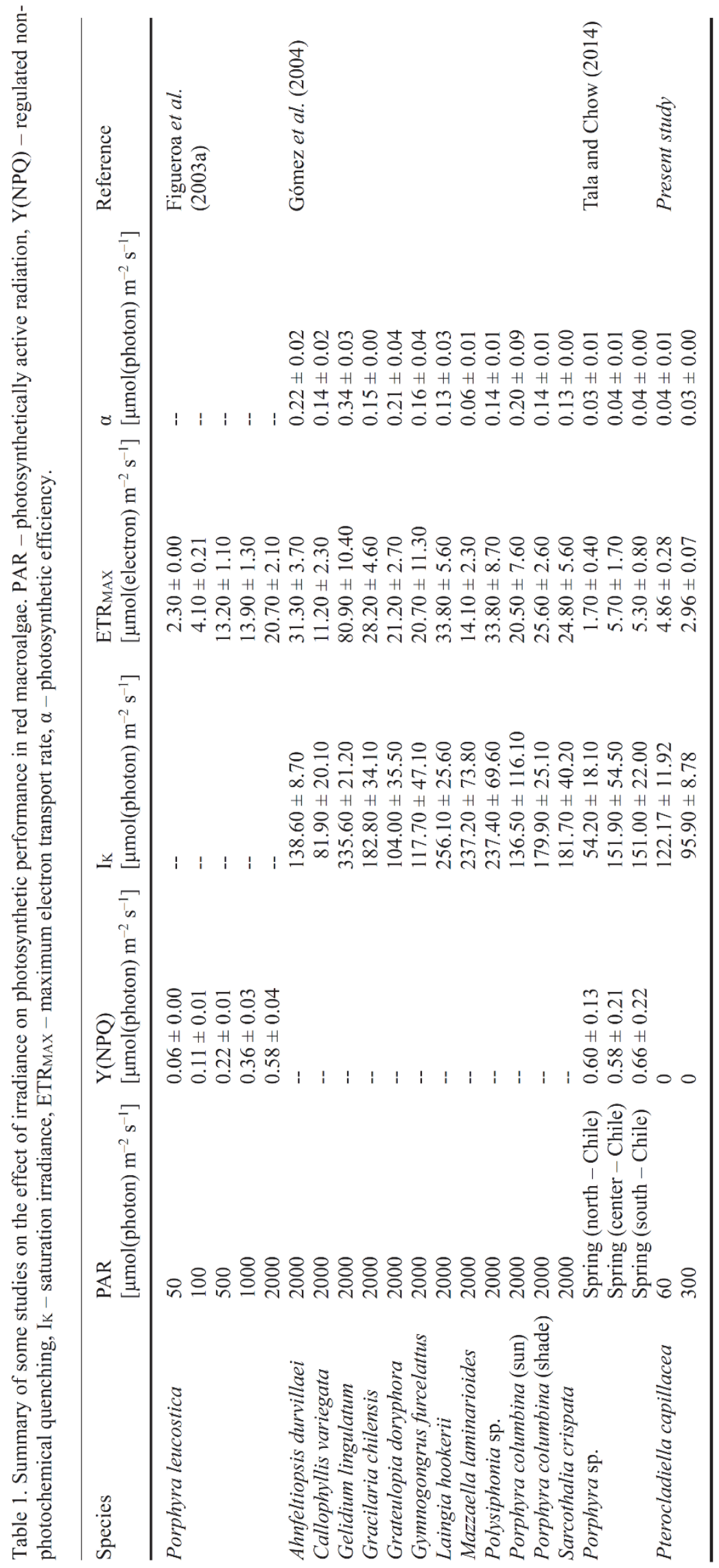


control conditions $\left[60 \mu \mathrm{mol}\right.$ (photon) $\mathrm{m}^{-2} \mathrm{~s}^{-1}$ ] represented photostress conditions for Gracilariopsis tenuifrons (C.J. Bird \& E.C. Oliveira) Fredericq \& Hommersand (Serra 2013, Torres et al. 2014), since photoinhibition of photosynthesis and photodamage of photosynthetic pigments were registered.

Low values of $\mathrm{F}_{\mathrm{V}} / \mathrm{F}_{\mathrm{M}}$ indicate that the algae are less tolerant to high radiation. Red algae usually have a lower $\mathrm{F}_{\mathrm{V}} / \mathrm{F}_{\mathrm{M}}$ than that of green and brown macroalgae (Chaloub et al. 2010), as observed for P. capillacea. Low ETR curves at $300 \mu \mathrm{mol}$ (photon) $\mathrm{m}^{-2} \mathrm{~s}^{-1}$ could be expected for a shade-adapted alga, then the capacity for transfer and transport electrons through the electron transport chain of the photosystem is adapted for reducing the transport rate to avoid photoxidative excessive energy and oxidative stress (Bautista and Necchi 2008).
Comparing the photosynthetic parameters of $P$. capillacea with published results for other rhodophytes on the effect of increasing PAR (Table 1), variable responses can be noted. In this compilation data, it is worth highlighting the results of $\mathrm{Y}_{(\mathrm{NPQ})}$. In the present study, none of the irradiances used activated $\mathrm{Y}_{(\mathrm{NPQ})}$, thus $P$. capillacea did not dissipate heat with energy expenditure. In contrast, Table 1 shows that Porphyra species under four increasing irradiances activated this defense mechanism.

Changes in accessory pigments are among the first evidence observed under excessive irradiance, in the case of red algae, these are phycobiliproteins and carotenoids (Schmidt et al. 2012). At high irradiance, these pigments regulate photosynthetic activity by efficiently dissipating excess energy through fluorescence (Del Campo et al. 2007, Heldt and Piechulla 2011). The antenna complexes

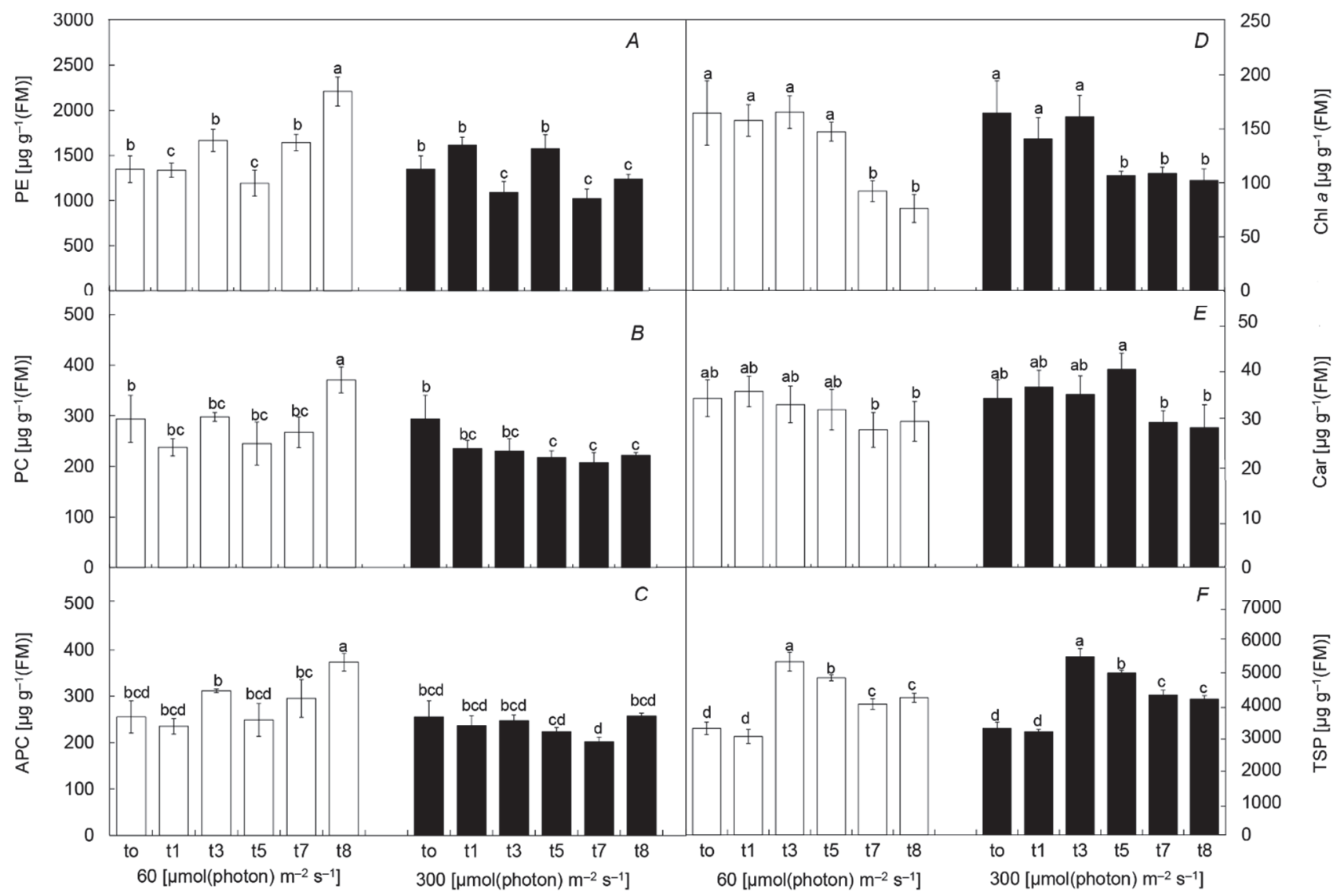

Fig. 4. Effect of 60 (white bars) and 300 (black bars) $\mu \mathrm{mol}\left(\right.$ photon) $\mathrm{m}^{-2} \mathrm{~s}^{-1}$ on $(A) \mathrm{PE}-$ phycoerythrin, $(B) \mathrm{PC}-$ phycocyanin, (C) APC - allophycocyanin, $(D) \mathrm{Chl} a$ - chlorophyll $a,(E)$ Car - carotenoids, and $(F)$ TSP - total soluble proteins of Pterocladiella capillacea over the experimental time (mean $\pm \mathrm{SD}, n=5$ ). Different letters represent statistically differences by repeated-measure ANOVA and post hoc Newman-Keuls test $(p<0.05)$. 


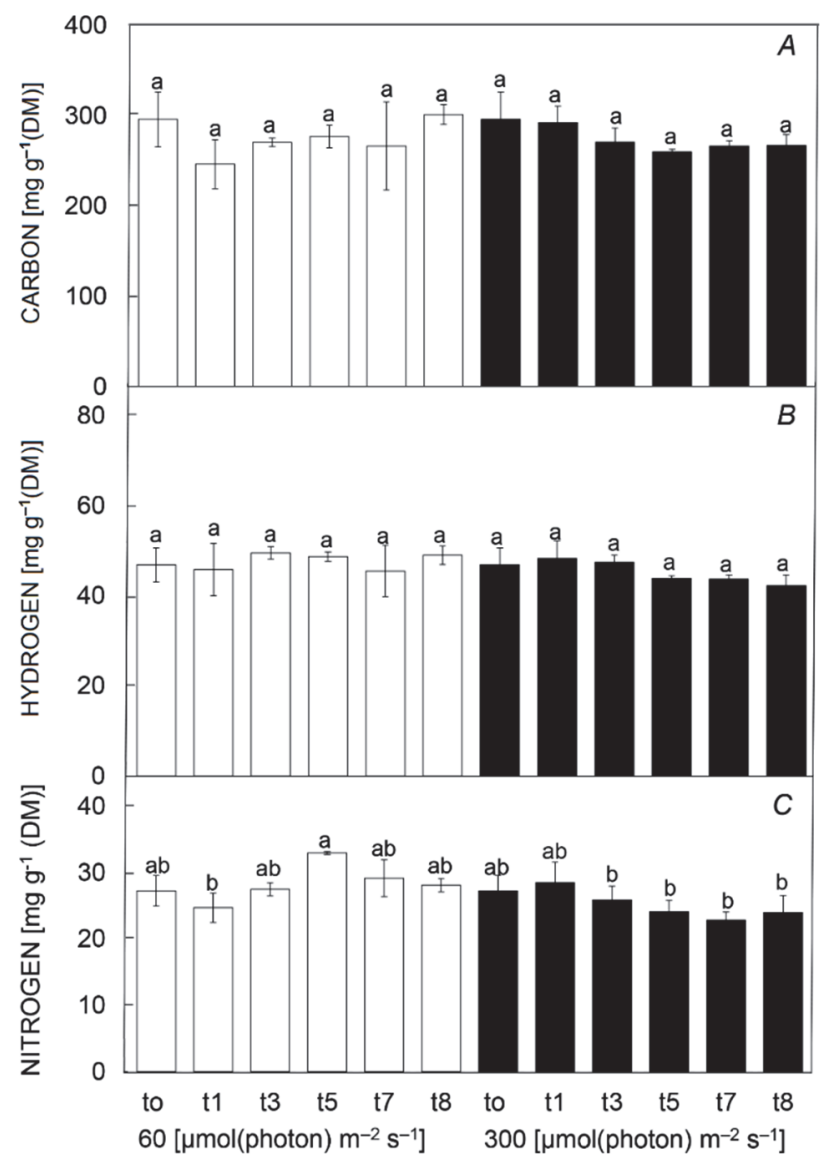

Fig. 5. Effect of 60 (white bars) and 300 (black bars) $\mu$ mol(photon) $\mathrm{m}^{-2} \mathrm{~s}^{-1}$ on the cellular contents of $(A)$ carbon, $(B)$ hydrogen, and (C) nitrogen of Pterocladiella capillacea over the experimental time (mean $\pm \mathrm{SD}, n=5$ ). Different letters represent statistically differences by repeated-measure ANOVA and post hoc Newman-Keuls test $(\mathrm{p}<0.05)$.

of PSI in red algae are composed of protein-pigment complexes intrinsic to the membranes. The pigments, which form this antenna complexes, are Chl $a$ and Car, such as zeaxanthin and $\beta$-carotene (Gantt 1990).

Ursi et al. (2003) reported the existence of violaxanthin cycle in Gracilaria birdiae E.M. Plastino \& E.C. Oliveira, but the existence of the xanthophyll cycles in Rhodophyta is still uncertain although several species show high concentrations of zeaxanthin (Goss and Jacob 2010). The diversity of mechanisms for photoaclimation and photoprotection in red algae are related to the types of Car present and acting as antioxidants and in the deactivation of reactive oxygen species, protecting the photosynthetic apparatus (Sampath-Wiley et al. 2008, Schubert et al. 2011).

Additionally, the arrangement of phycobiliproteins in the external membrane of the thylakoids facilitates the neutralization of reactive species that could damage the photosynthetic apparatus (Schubert and Mendoza-García 2008). When high irradiance exposure becomes potentially harmful, these pigments usually decline as a photoprotection mechanism, in order to reduce excessive harvesting of energy and to avoid the photoxidation of the D1 proteins in the photosystems (Adir et al. 2003).

Photoacclimation processes by $\mathrm{Y}_{(\mathrm{NO})}$ at moderate light seem to be adequate and efficient for $P$. capillacea, whereas minimal variations were observed in pigment concentrations. These results reinforce the hypothesis that the irradiance of $300 \mu \mathrm{mol}$ (photon) $\mathrm{m}^{-2} \mathrm{~s}^{-1}$ was not a condition that caused photodamage to $P$. capillacea. Discoloration of the apical segments is a strong evidence for the pigment loss. However, this situation was not observed in $P$. capillacea. Under higher irradiances, 600 and 1,000 $\mu$ mol(photon) $\mathrm{m}^{-2} \mathrm{~s}^{-1}$, Torres et al. (2014) observed an acute and chronical effect on a pigment content for G. tenuifrons. The authors suggested that the decrease in the antenna complex is a strategy to reduce light absorption by the alga and thus avoid excessive photo-oxidation. Similar results at high irradiance were also registered for other red algae, e.g., Levy and Gantt (1988) for Porphyridium purpureum (Bory de Saint-Vincent) K.M. Drew \& R. Ross, Carnicas et al. (1999) for Gracilaria tenuistipitata C.F. Chang \& B.M. Xia, Sudatti et al. (2011) for L. dendroidea, and Serra (2013) for G. tenuifrons. 


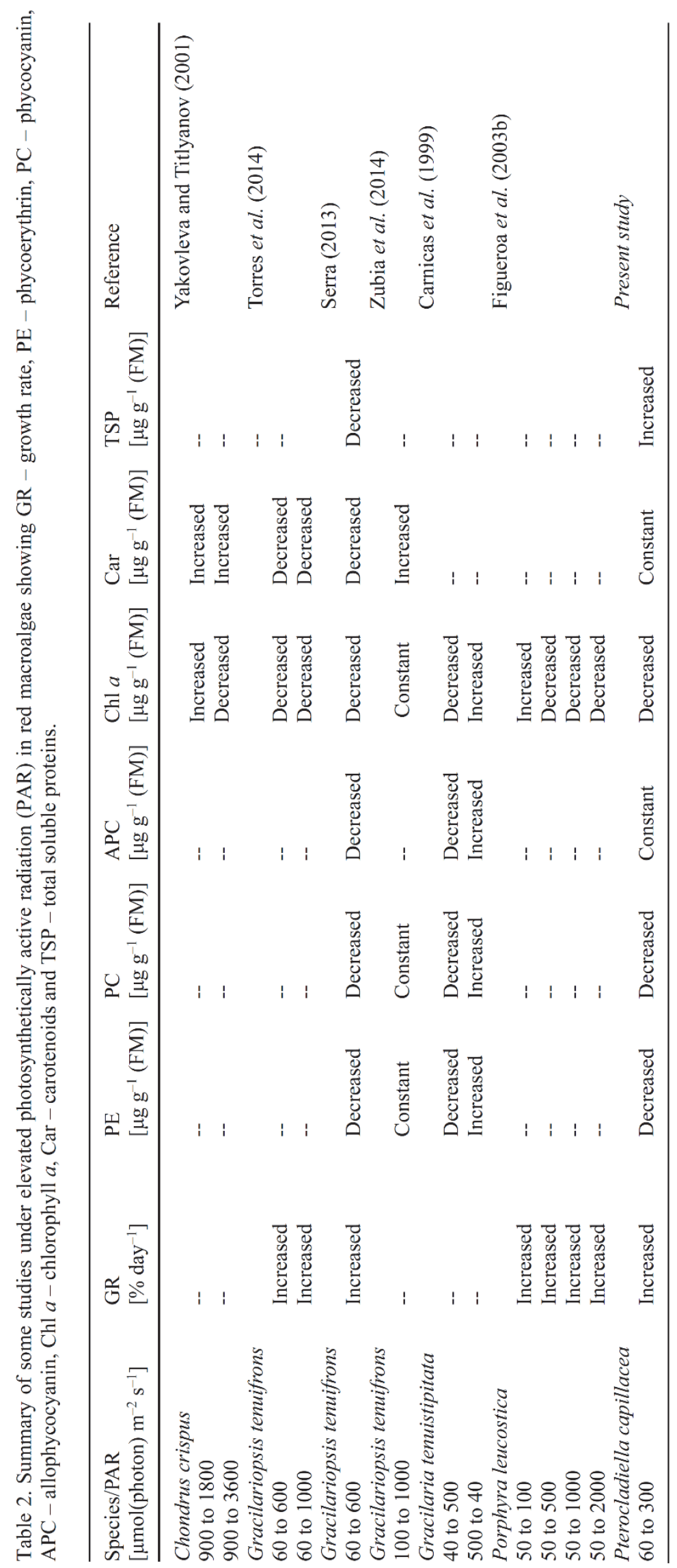


The differences observed for Chl $a$ and TPS over time (a tendency of inverse relationship with decreasing Chl $a$ from the third day and increasing TSP from the second day) may be also related to the imbalance in carbon/ nitrogen metabolism. The nutritional and photosynthetic demands could be explained by the degradation and synthesis of these components, as an acclimation mechanism for dealing with variations of light intensity (Figueroa et al. 2009).

The reduction of the Chl $a$ content can be interpreted as a defense mechanism to avoid overloading the photosynthetic system, which could result in the formation of reactive oxygen species. Then the carbon/nitrogen demand can require differential metabolic energy for photosynthetical performance and accumulation of carbon and nitrogen into organic molecules (Gordillo et al. 2001, Figueroa et al. 2014b). According to Huertas et al. (2000), in addition to irradiance, the availability of intracellular $\mathrm{C}$ and $\mathrm{N}$ is a key factor for growth, since these elements can contribute to processes of organic matter accumulation and increased productivity. For some photosynthetic organisms, an increasing demand for nutrients causes a starving-induced response, which induces a transient improvement of the metabolic response (Smit 2002, Figueroa et al. 2009).

The increase in TSP over time could be stimulated under moderate light intensity to improve the protein content, strengthen the GR, and improve the nutritional composition for a longer period of cultivation. In macroalgae, the TSP content seems to be directly related to nutrient availability and not necessarily to irradiance. Andria et al. (1999) observed that the content of TSP in Gracilaria sp. decreased when the species was cultivated at low $\mathrm{N}$ availability, while Collén et al. (2004) observed similar results with $G$. tenuistipitata. In contrast, the light green and brown lineages of the red macroalgae Hypnea musciformis (Wulfen) J.V. Lamouroux accumulated proteins under increased nitrate concentration (Martins et al. 2009). Thus, $P$. capillacea could be used as a target species for the accumulation of proteins, aiming to use these compounds as functional ingredients.

The results of GR, photosynthetic pigments, and TSP of $P$. capillacea were compared to those reported for other red algae under increasing PAR (Table 2). It is noted that red algae responses vary by light intensity or species. All the summarized studies showed increased GR under elevated irradiance, similar to that observed in this study for $P$. capillacea under moderate increasing light intensity, despite exhibiting different responses for photosynthetic pigments. All studies showed the decrease in PE, PC, and APC, when comparing a higher irradiance relative to lower light intensity, except for G. tenuifrons (Zubia et al. 2014) where PE, PC, and APC remained constant, similarly to that observed for $P$. capillacea. Data for Chl $a$ and Car showed variable responses including decreasing, constant, and increasing contents. Opposite responses were also observed for TSP.

Summarizing all the analyzed descriptors and treatments over time, the results clearly showed the physiological sensitivity of $P$. capillacea, where the increase of irradiance at moderate level activated the acclimation responses without compromising or subchronical effect on photosynthetic performance, antenna complex, GR, and protein content. Oxidative stress and photodamage was not observed in $P$. capillacea, indicating efficient tolerance through $\mathrm{Y}_{(\mathrm{NO})}$ energy dissipation. Additionally, the results presented here indicate the possibility of stimulating the GR and protein content of $P$. capillacea under moderately increasing light conditions. This response is interesting because it can represent an improved productivity of a cultivation system and the management in natural banks for functional natural products. However, higher light intensity for a shade alga can implicate unfavorable responses that may compromise GR, promoting photosynthetic photoinhibition and oxidative deleterious effects. $P$. capillacea has a phenology of major biomass production in colder seasons rather than in the summer. The photodamage and low photosynthesis recorded at high irradiance indicate that $P$. capillacea is an alga adapted to the shade conditions (Coutinho and Yoneshigue 1988, Lee and Shiu 2009).

Studies on acclimation, tolerance, and recovery responses are an important tool for basic knowledge of the biology of the species, as well as the implications on ecophysiological aspects as management, monitoring, environmental pollution, and global climate changes and considerations for biotechnological applications. Additionally, the understanding of the physiology and ecological responses of macroalgae to light energy is of fundamental importance to explain in situ physiological behavior and to predict ecological consequences in coastal ecosystems as a result of the increase in irradiance and UV radiation due to the reduction of the ozone layer. Finally, given the ability of $P$. capillacea to acclimate its photosynthetic performance to moderate irradiance, we suggest further studies on the physiology of the species with another abiotic factors, such as temperature and nutrient availability. This integration could contribute to complementary knowledge for a better understanding of important ecophysiological implications for the cultivation, sustainable exploitation, and management of $P$. capillacea, given the great economic and ecological importance of the species. 


\section{References}

Adir N., Zer H., Shochat S. et al.: Photoinhibition: a historical perspective. - Photosynth. Res. 76: 343-370, 2003.

Andria J.R., Vergara J.J., Perez-Llorens J.L.: Biochemical responses and photosynthetic performance of Gracilaria sp. (Rhodophyta) from Cádiz, Spain, cultured under different inorganic carbon and nitrogen levels. - Eur. J. Phycol. 34: $497-$ 504, 1999.

Asada K.: Mechanisms for scavenging reactive molecules generated in chloroplasts under light stress. - In: Baker N.R., Bowyer J.R. (ed.): Photoinhibition of Photosynthesis: From Molecular Mechanisms to the Field. Pp. 129-142. Bios. Sci. Publ., Oxford 1994.

Balboa E.M., Conde E., Moure A., et al.: In vitro antioxidant properties of crude extracts and compounds from brown algae. - Food Chem. 138: 1764-1785, 2013.

Bautista A.I.N., Necchi O. Jr.: Photoacclimation in a tropical population of Cladophora glomerata (L.) Kützing 1843 (Chlorophyta) from southeastern. - Braz. J. Biol. 68: 129-36, 2008.

Beach K.S., Smith C.M., Okano R.: Experimental analysis of rhodophyte photoacclimation to PAR and UV-radiation using in vivo absorbance spectroscopy. - Bot. Mar. 43: 525-536, 2000.

Betancor S., Tuya F., Gil-Díaz T. et al.: Effects of a submarine eruption on the performance of two brown seaweeds. - J. Sea Res. 87: 68-78, 2014.

Bradford M.: A rapid sensitive method for the quantification of microgram quantities of protein utilizing the principle of protein-dye binding. - Anal. Biochem. 72: 248-254, 1976.

Carnicas E., Jiménez C., Niell F.X.: Effects of changes of irradiance on the pigment composition of Gracilaria tenuistipitata var. liui Zhang et Xia. - J. Photoch. Photobio. B 50: 149-158, 1999.

Chaloub R.M, Reinert F., Nassar C.A.G. et al.: Photosynthetic properties of three Brazilian seaweeds. - Rev. Bras. Bot. 33: 371-374, 2010.

Cherry J.H., Nielsen B.L.: Metabolic engineering of chloroplasts for abiotic stress tolerance. - In: Daniell H., Chase C.D. (ed.): Molecular Biology and Biotechnology of Plant Organelles. Pp. 513-525. Springer, Dordrecht 2004.

Collén P.N., Camitz A., Hancock R.D. et al.: Effect of nutrient deprivation and resupply on metabolites and enzymes related to carbon allocation in Gracilaria tenuistipitata (Rhodophyta). - J. Phycol. 40: 305-314, 2004.

Copertino M.S., Cheshire A., Watling J.: Photoinhibition and photoacclimation of turf algal communities on a temperate reef, after in situ transplantation experiments. - J. Phycol. 42: 580592,2006

Coutinho R., Yoneshigue Y.: Diurnal variation in photosynthesis vs. irradiance curves from "sun" and "shade" plants of Pterocladia capillacea (Gmelin) Bornet et Thuret (Gelidiaciaceae: Rhodophyta) from Cabo Frio, Rio De Janeiro, Brazil. - J. Exp. Mar. Biol. Ecol. 118: 217-228, 1988.

Del Campo J.A., García-Gonzáles M., Guerrero M.G.: Outdoor cultivation of microalgae for carotenoid production: current states and perspectives. - Appl. Microbiol. Biotechnol. 74: 1763-1774, 2007.

Donkor V.A., Häder D.P.: Effects of ultraviolet irradiation on photosynthetic pigments in some filamentous cyanobacteria. Aquat. Microb. Ecol. 11: 143-149, 1996.

dos Santos R.W., Schmidt É.C., Martins R.P. et al.: Effects of cadmium on growth, photosynthetic pigments, photosynthetic performance, biochemical parameters and structure of chloroplasts in the agarophyte Gracilaria domingensis (Rhodophyta, Gracilariales). - Am. J. Plant Sci. 3: 1077-1084, 2012.

Edwards P.: Illustrated guide to the seaweeds and sea grasses in the vicinity of Porto Aransas, Texas. - In: Edwards P. (ed.): Seaweeds and Sea Grasses: Contributions in Marine Science, vol. 15. Pp. 132. B. J. Copeland, Texas 1970.

Falkowski P.G.: Light-shade adaptation in marine phytoplankton. - In: Falkowski P.G. (ed.): Primary Production in the Sea. Pp. 531. Plenum Press, New York 1980.

Figueroa F.L., Conde-Álvarez R., Gómez I.: Relations between electron transport rates determined by pulse amplitude modulated chlorophyll fluorescence and oxygen evolution in macroalgae under different light conditions. - Photosynth. Res. 75: 259-275, 2003a.

Figueroa F.L., Escassi L., Perez-Rodríguez E. et al.: Effects of short-term irradiation on photoinhibition and accumulation of mycosporine-like amino acids in sun and shade species of the red algal genus Porphyra. - J. Photoch. Photobio. B. 69: 21-30, 2003b.

Figueroa F.L., Martínez B., Israel A. et al.: Acclimation of red sea macroalgae to solar radiation: photosynthesis and thallus absorptance. - Aquat. Biol. 7: 159-172, 2009.

Figueroa F.L., Domínguez-González B., Korbee N.: Vulnerability and acclimation to increased UVB radiation in three intertidal macroalgae of different morpho-functional groups. Mar. Environ. Res. 97: 30-38, 2014a.

Figueroa F.L, Barufi B.J., Malta E.J. et al.: Short-term effects of increased $\mathrm{CO}_{2}$, nitrate and temperature on three Mediterranean macroalgae: photosynthesis and biochemical composition. Aquat. Biol. 22: 177-193, 2014b.

Franklin L.A., Larkum A.W.D.: Multiple strategies for a high light existence in a tropical marine macroalga. - Photosynth. Res. 53: 149-159, 1997.

Franklin L.A., Osmond C.B., Larkym A.W.D.: Photoinhibition, UV-B and Algal Photosynthesis. Pp. 352-375. Kluwer Academic Publishers, Berlin 2003.

Gal-Or S., Israel A.: Growth responses of Pterocladiella capillacea (Rhodophyta) in laboratory and outdoor cultivation. - J. Appl. Phycol. 16: 195-202, 2004.

Gantt E.: Pigmentation and photoacclimation. - In: Cole K.M., Sheath R.G. (ed.): Biology of the Red Algae. Pp. 203-219. Cambridge University Press, Cambridge 1990.

Gómez I., Huovinen P.: Morpho-functional patterns and zonation of South Chilean seaweeds: the importance of photosynthetic and bio-optical traits. - Mar. Ecol. Prog. Ser. 422: 77-91, 2011.

Gómez I., López-Figueroa F., Ulloa N. et al.: Patterns of photosynthesis in 18 species of intertidal macroalgae from southern Chile. - Mar. Ecol. Prog. Ser. 270: 103-116, 2004.

Gordillo F.J.L, Jiménez C., Goutx M. et al.: Effects of $\mathrm{CO}_{2}$ and nitrogen supply on the biochemical composition of Ulva rigida with especial emphasis on lipid class analysis. - J. Plant Physiol. 158: 367-373, 2001.

Goss R., Jacob T.: Regulation and function of xanthophyll cycledependent photoprotection in algae. - Photosynth. Res. 106: 103-122, 2010.

Grobbelaar J.U., Kurano N.: Use of photoacclimation in the design of a novel photobioreactor to achieve high yields in algal mass cultivation. - J. Appl. Phycol. 15: 121-126, 2003.

Grzymski J., Johnsen G., Sakshaug E.: The significance of intra- 
cellular self-shading on the bio-optical properties of brown, red and green macroalgae. - J. Appl. Phycol. 33: 408-414, 1997.

Guimarães S.M.P.B.: A revised checklist of benthic marine Rhodophyta from the state of Espírito Santo, Brazil. - Bol. Inst. Bot. 17: 143-194, 2006.

Hanelt D., Figueroa F.L.: Physiological and photomorphogenic effects of light on marine macrophytes. - In: Wiencke C., Bischof K. (ed.): Seaweed Biology: Novel Insights into Ecophysiology, Ecology and Utilization, Vol. 219. Pp. 3-23. Springer, Heidelberg 2012.

Hanelt D., Hawes I., Rae R.: Reduction of UV-B radiation causes an enhancement of photoinhibition in high light stressed aquatic plants from New Zealand lakes. - J. Photoch. Photobio. B 84: 89-102, 2006.

He L.H., Wu M., Qian P.Y. et al.: Effects of co-culture and salinity on the growth and agar yield of Gracilaria tenuistipitata var. liui Zhang et Xia. - Chin. J. Oceanol. Limnol. 20: 365-370, 2002.

Heldt H-W., Piechulla B.: Plant Biochemistry, $4^{\text {th }}$ ed. Pp. 618. Elsevier, Burlington 2011.

Hideg E., Spetea C., Vass I.: Singlet oxygen and free-radical production during acceptor-induced and donor-side-induced photoinhibition: studies with spin-trapping EPR spectroscopy. - BBA-Bioenergenetics 1186: 143-152, 1994.

Hou X., Hou H.J.: Roles of manganese in photosystem II dynamics to irradiations and temperatures. - Front Biol. 8: 312-322, 2013.

Huertas E., Montero O., Lubián L.M.: Effects of dissolved inorganic carbon availability on growth, nutrient uptake and chlorophyll fluorescence of two species of marine microalgae. - Aquacult. Eng. 22: 181-197, 2000.

Jassby A.D., Platt T.: Mathematical formulation of the relationship between photosynthesis and light for phytoplankton. Limnol. Oceanogr. 21: 540-547, 1976.

Klughammer C., Schreiber U.: Complementary PSII quantum yields calculated from simple fluorescence parameters measured by PAM fluorometry and the saturation pulse method. PAM Appl. Notes. 1: 27-35, 2008.

Kursar T.A., van der Meer J., Alberte R.S.: Light-harvesting system of the red alga Gracilaria tikvahiae. I. Biochemical analyses of pigments mutation. - Plant Physiol. 73: 353-360, 1983.

Lee T.M., Shiu C.T.: Implications of mycosporine-like amino acid and antioxidant defences in UV-B radiation tolerance for the algae species Pterocladiella capillacea and Gelidium amansii. - Mar. Environ. Res. 67: 8-16, 2009.

Levy I., Gantt E.: Light acclimation in Porphyridium purpureum (Rhodophyta): growth, photosynthesis, and phycobilisomes. J. Appl. Phycol. 24: 452-458, 1988.

Lichtenthaler H.K., Buschmann C.: Chlorophylls and carotenoids: measurement and characterization by UV-VIS spectroscopy. - In: Wrolstad R.E., Acree T.E., An H. et al. (ed.): Current Protocols in Food Analytical Chemistry. Pp. F4.3.1F4.3.8. John Wiley \& Sons, New York 2001.

Liu F., Pang S.J.: Stress tolerance and antioxidant enzymatic activities in the metabolisms of the reactive oxygen species in two intertidal red algae Grateloupia turuturu and Palmaria palmate. - J. Exp. Mar. Biol. Ecol. 382: 82-87, 2010.

MacIntyre H.L., Kana T.M., Geider R.J.: The effect of water motion on short-term rates of photosynthesis by marine phytoplankton. - Trends Plant Sci. 5: 12-17, 2000.

Martínez B., Rico J.: Changes in nutrient content of Palmaria palmata in response to changes in nutrient to variable light and upwelling in northern Spain. - J. Phycol. 44: 50-59, 2008.

Martins A.P., Chow F., Yokoya N.S.: [In vitro assay of nitrate reductase enzyme and effect of nitrate and phosphate availability in colour strains of Hypnea musciformis (Wulfen) J. V. Lamour. E. (Gigartinales, Rhodophyta)]. - Rev. Bras. Bot. 32: 635-645, 2009. [In Portuguese]

Martone P. T., Alyono M., Stites S.: Bleaching of an intertidal coralline alga: untangling the effects of light, temperature and desiccation. - Mar. Ecol. Prog. Ser. 416: 57-67, 2010.

Maxwell K., Johnson G.N.: Chlorophyll fluorescence: a practical guide. - J. Exp. Bot. 51: 659-668, 2000.

Mercado J.M., Jiménez C., Niell F.X. et al.: Comparison of methods for measuring light absorption by algae and their application to the estimation of package effect. - Sci. Mar. 60: 39-45, 1996.

Nascimento E.F.I., Rosso S.: [Fauna associated with benthic marine macroalgae (Rhodophyta and Phaeophyta) from São Sebastião, São Paulo]. - Rev. Bras. Ecol. 11: 38-52, 2007. [In Portuguese]

Necchi O. Jr.: Light-related photosynthetic characteristic of freshwater Rhodophyta. - Aquat. Bot. 82: 193-20, 2005.

Nishihara G.N., Terada R., Noro T.: Effect of temperature and irradiance on the uptake of ammonium and nitrate by Laurencia brongniartii (Rhodophyta, Ceramiales). - J. Appl. Phycol. 17: 371-377, 2005.

Nishiyama Y., Allakhverdiev S., Yamamoto H. et al.: Singlet oxygen inhibits the repair of photosystem II by suppressing translation elongation of the D1 protein in Synechocystis sp. Biochemistry 43: 11321-11330, 2004.

Nyvall-Cóllen P., Camitz A., Hancock R.D. et al.: Effect of nutrient deprivation and resupply on metabolites and enzymes related to carbon allocation in Gracilaria tenuistipitata (Rhodophyta). - J. Appl. Phycol. 40: 305-314, 2004.

Oliveira E.C., Saito R.M., Neto J.F.S. et al.: Temporal and spatial variation in agar from a population of Pterocladia capillacea (Gelidiales, Rhodophyta) from Brazil. - Hydrobiologia 326: 501-504, 1996.

Park J.J., Han T., Choi E.M.: Differences in the oxidative stress and antioxidant responses of three marine macroalgal species upon UV exposure. - Toxicol. Environ. Health Sci. 8: 101-107, 2016.

Penniman C.A., Mathieson A.C., Penniman C.E.: Reproductive phenology and growth of Gracilaria tikvahiae McLachlan (Gigartinales, Rhodophyta) in the Great Bay Estuary, New Hampshire. - Bot. Mar. 29: 147-154, 1986.

Polo L.K., Felix M.R.L., Kreusch M. et al.: Metabolic profile of the brown macroalga Sargassum cymosum (Phaeophyceae, Fucales) under laboratory UV radiation and salinity conditions. - J. Appl. Phycol. 90: 560-571, 2014.

Ramus J., Rosenberg G.: Diurnal photosynthetic performance of seaweeds measured under natural conditions. - Mar. Biol. 56: 21-28, 1980.

Roháček K.: Chlorophyll fluorescence parameters: the definitions, photosynthetic meaning, and mutual relationships. Photosynth. Res. 40: 13-29, 2002.

Sampath-Wiley P., Neefus C., Jahnke L.: Seasonal effects of sun exposure and emersion on intertidal seaweed physiology: fluctuations in antioxidant contents, photosynthetic pigments and photosynthetic efficiency in the red alga Porphyra umbilicalis Kützing (Rhodophyta, Bangiales). - J. Exp. Mar. Biol. Ecol. 361: 83-91, 2008.

Schmidt E.C., Pereira B., Pontes C.L.: Alterations in architecture and metabolism induced by ultraviolet radiation- $\mathrm{B}$ in the 
carragenophyte Chondracanthus teedei Rhodophyta, Gigartinales. - Protoplasma 249: 353-367, 2012.

Schreiber U., Schliwa U., Bilger W.: Continuous recording of photochemical and non-photochemical chlorophyll fluorescence quenching with a new type of modulation fluorometer. - Photosynth. Res. 10: 51-62, 1986.

Schreiber U., Neubauer C.: $\mathrm{O}_{2}$-dependent electron flow, membrane energization and the mechanism of non-photochemical quenching of chlorophyll fluorescence. - Photosynth. Res. 25: 279-293, 1990.

Schubert N., García-Mendoza E.: Photoinhibition in red algal species with different carotenoid profiles. - J. Phycol. 44: 1437-1446, 2008.

Schubert N., García-Mendoza E., Enríquez S.: Is the photoacclimation response of Rhodophyta conditioned by the species carotenoid profile? - Limnol. Oceanogr. 56: 2347-2361, 2011.

Serra D.R.: [Gracilariopsis tenuifrons (Gracilariales - Rhodophyta) Response to Irradiance Stimuli in vitro]. - Masters Dissertation. Pp. 97. Institute of Bioscience, University of São Paulo, São Paulo 2013. [In Portuguese]

Sudatti D.B., Fujii M.T., Rodrigues S.V.: Effects of abiotic factors on growth and chemical defenses in cultivated clones of Laurencia dendroidea J. Agardh (Ceramiales, Rhodophyta). Mar. Biol. 158: 1439-1446, 2011.

Smit A.J.: Nitrogen uptake by Gracilaria gracilis (Rhodophyta): adaptations to a temporally variable nitrogen environment. Bot. Mar. 45: 196-209, 2002.

Takahashi S., Badger M.R.: Photoprotection in plants: a new light on photosystem II damage. - Trends Plant Sci. 16: 53-60, 2011.
Takahashi S., Murata N.: How do environmental stress accelerate photoinhibition? - Trends Plant Sci. 3: 178-182, 2008.

Tala F., Chow F.: Phenology and photosynthetic performance of Porphyra spp. (Bangiophyceae, Rhodophyta): seasonal and latitudinal variation in Chile. - Aquat. Bot. 113: 107-116, 2014.

Torres P.B., Chow F., Santos D.Y.A.C.: Growth and photosynthetic pigments of Gracilariopsis tenuifrons (Rhodophyta, Gracilariaceae) under high light in vitro culture. - J. Appl. Phycol. 27: 1243-1251, 2014.

Ursi S., Plastino E.M.: [Growth of reddish and light green strains of Gracilaria sp. (Gracilariales, Rhodophyta) in two culture media: analysis of different reproductive phases]. - Rev. Bras. Bot. 24: 587-594, 2001. [In Portuguese]

Ursi S., Pedersén M., Plastino E. et al.: Intraspecific variation of photosynthesis, respiration and photoprotective carotenoids in Gracilaria birdiae (Gracilariales: Rhodophyta). - Mar. Biol. 142: 997-1007, 2003.

Wanderley A.: [Effect of Nitrate Availability on Growth, Nitrate Reductase Activity, Chemical Composition and Nitrate and Phosphate Uptake in Gracilariopsis tenuifrons (Gracilariales, Rhodophyta)]. - Masters Dissertation. Pp. 140. Institute of Bioscience, University of São Paulo, São Paulo, 2009. [In Portuguese]

Yakovleva I.M., Titlyanov E.A.: Effect of high visible and UV irradiance on subtidal Chondrus crispus: stress photoinhibition and protective mechanisms. - Aquat. Bot. 71: 47-61, 2001.

Zubia M., Freile-Pelegrín Y., Robledo D.: Photosynthesis, pigment composition and antioxidant defences in the red alga Gracilariopsis tenuifrons (Gracilariales, Rhodophyta) under environmental stress. - J. Phycol. 26: 2001-2010, 2014. 